\title{
Forecasting Greenhouse Gas Emissions from Heavy Vehicles: A Case Study of Semarang City
}

\section{Mochamad Arief Budihardjo ${ }^{1 *}$, Isaaf Faadhilah', Natasya Ghinna Humaira ${ }^{2}$, Mochtar Hadiwidodo', Irawan Wisnu Wardhana', Bimastyaji Surya Ramadan²}

'Department of Environmental Engineering, Faculty of Engineering, Universitas Diponegoro, Semarang50275, Indonesia

${ }^{2}$ Environmental Sustainability Research Group, Department of Environmental Engineering, Faculty of Engineering, Universitas Diponegoro, Semarang-50275, Indonesia

*Corresponding Author, email: m.budihardjo@ft.undip.ac.id

\section{c) (i) (2)}

\begin{abstract}
In Indonesia, transportation, especially by road, consumes more energy than any other sector. The increasing number of vehicles on the roads also means energy consumption and greenhouse gas (GHG) emissions are likely to increase. Vehicle emissions have been recognized as a significant contributor to atmospheric GHG pollution. Heavy-duty vehicles are considered to be the primary sources of vehicular emissions in most cities. It is therefore crucial to form projections of possible future emissions from heavy-duty vehicles in order to support policymakers in identifying which vehicles are most responsible for GHG emissions and in developing pollution control strategies. This study aims to forecast heavy-duty vehicle population, vehicle kilometers traveled (VKT), fuel consumption, and heavy-duty vehicle emissions using data from Semarang City, in order to demonstrate the GHG emissions of large cities in Indonesia. The 'Business as Usual' (BAU) method and methods used by the Intergovernmental Panel on Climate Change (IPCC) are incorporated to form a reliable projection of future vehicle emissions. It is found that heavy-duty vehicle emissions overall are likely to increase by 12,317 to $22,865 \mathrm{Gg} \mathrm{CO}_{2} / \mathrm{year}$ between 2021 and 2030; in 2030, emissions from trucks and buses are likely to be around 21,981.5 Gg $\mathrm{CO}_{2} /$ year and $884.2 \mathrm{Gg} \mathrm{CO}_{2} /$ year, respectively.
\end{abstract}

Keywords: BAU, IPCC, vehicle emissions, VKT

\section{Introduction}

The high levels of greenhouse gas (GHG) emissions being released into the atmosphere have become a significant concern in many countries (Pauzi and Abdullah, 2014). The transportation sector is one of the most significant sources of GHG emissions. In 2019, transportation consumed more energy than any other economic sector in Indonesia. The amount of energy required for transportation in Indonesia is about $40 \%$ of the total national energy requirement; this is equivalent to 414.98 million barrels of oil (Ministry of Energy and Mineral Resources Republic of Indonesia, 2019). Approximately 73\% of total GHG emissions from the global transportation sector come from road transportation (Japan Automobile Manufacturers Association, 2008). This number is likely to continue to increase, in line with the increasing number of vehicles on the road. 
Vehicle emissions have been recognized as a significant contributor to air pollution globally, causing disadvantageous effects on air quality and human health (Anenberg et al., 2017; He et al., 2016). The rapid growth of the vehicle population in megacities has been recognized as an important source of atmospheric pollution (Song et al., 2017). Vehicle emissions which can potentially harm the environment include carbon dioxide $\left(\mathrm{CO}_{2}\right)$, carbon monoxide $(\mathrm{CO})$, hydrocarbon $(\mathrm{HC})$, nitrogen oxide $\left(\mathrm{NO}_{\mathrm{x}}\right)$, particulate matter $(\mathrm{PM})$, and sulfur dioxide $\left(\mathrm{SO}_{2}\right) . \mathrm{CO}_{2}$ in particular is the most significant $\mathrm{GHG}$ in the atmosphere in terms of long-term effects (Wulandari, 2020). It is necessary to establish a series of policies to control vehicle pollution, reduce fossil fuel use and build transportation facilities. These policies will have a long-term impact on the vehicle population and on vehicle emission characteristics (Wu et al., 2016). Heavy-duty vehicles are currently the primary sources of vehicular emissions in cities because the emission factors of heavy-duty vehicles are much higher than those of light-duty vehicles (Wang et al., 2008). Therefore, it is essential to form projections of heavy-duty vehicle emissions in megacities.

Semarang City is one of the biggest cities in Indonesia, with an area of $373.7 \mathrm{~km}^{2}$ and a population of 1.8 million people. The population grows by approximately $1.57 \%$ per year, and the gross domestic product (GDP) of the city grows at 7.73\% (Central Bureau of Statistics of Semarang City, 2020). According to Liu et al. (2017); Wu et al. (2014), GDP per capita is closely related to energy demand and to vehicle emissions. Currently, Semarang City contains 615,396 heavy-duty vehicles. The number of vehicles in the city increases by $6.9 \%$ per year, on average.

Therefore, this study aims to calculate a large-scale city-level projection of heavy-duty vehicle population, vehicle kilometers traveled (VKT), fuel consumption and heavy-duty vehicle emissions. This study is limited to heavy-duty vehicles registered to Semarang City. The results of this study could be used to develop multi-year road transportation emission inventories at the national, regional, and city levels. These results can also support policymakers by making them aware of potential future vehicle emissions. The results of this study could be used as a reference for planning pollution control strategies.

\section{Methods}

Emissions projections were carried out based on data from 2016-2020, which was also used for calculating emissions. The forecasting years were set as 2021-2035. It was assumed that no changes in regulation and policy will limit the growth of the vehicle population or reduce vehicle emissions. This study calculates $\mathrm{CO}_{2}$ emissions from heavy-duty vehicles such as buses and trucks, not any other GHG emissions.

\subsection{Data Collection}

The primary data used in this study were 'vehicle kilometers travelled' (VKT). These data were obtained from five major service stations and three vehicle dealers in Semarang City. Meanwhile, other information was obtained from relevant agencies, literature, and regulations. Relevant agencies include the Central Java Police Traffic Service, Transportation Services, National Planning and Development Agency, and private companies.

\subsection{Business as Usual (BAU)}

The projection in this study uses the Business as Usual (BAU) method. BAU is a method of estimating calculations in the absence of new policies or activities. When calculating a projection using the BAU scenario, the projection will continue to increase using the growth rate at the time of calculation. The BAU method assumes that there will be no interruption to this rate due to changes in regulation or any other event (Sun et al., 2020). This study also follows the baseline guidelines for conducting an emission inventory as defined by the Indonesian government in the Guidelines for Implementing the National Greenhouse Gas Inventory (Bappenas, 2014).

The projection of GHG emissions was performed using data on GDP, heavy-duty vehicle ownership, and heavy-duty vehicle population. Previous and current growth rates in heavy-duty 
population were used as initial data in order to project the population of heavy-duty vehicles in the future. These numbers were obtained by averaging the yearly growth rate of the heavy-duty vehicle population from 2015-2020, resulting in an average growth rate of $0.92 \%$ per year. The following equation estimates the future heavy-duty vehicle population:

$$
P(y)=(P G+1) x P(y-1)
$$

where $\mathrm{P}$ is the heavy-duty vehicle population, $\mathrm{y}$ is the year for which the estimate is being made, and PG is the growth rate per year of the heavy-duty vehicle population.

The GDP projection describes the ability of the population to buy heavy-duty vehicles in the years between 2021 and 2030. In order to project future GDP, growth rates were calculated using the average yearly grwoth in GDP from 2015-2020, which was 7.73\%. The following equation estimates the future GDP for a given year under the BAU scenario:

$$
G(y)=(G G+1) * P(y-1)
$$

where G represents GDP GG represents the GDP growth rate per year, P represents the heavy-duty vehicle population and y represents the year for which the estimate is being made.

In order to project ownership of heavy-duty vehicles, two variables were tested using a linear regression model. The resulting linear regression analysis graph indicates a high correlation between the two variables vehicle category and GDP per capita $\left(\mathrm{R}_{2}=0.9\right)$. The projection of heavy-duty vehicle ownership was calculated by an equation which makes use of the results of the regression analysis:

$$
\mathrm{VP}(\mathrm{y})=\mathrm{VO}(\mathrm{y}) * \mathrm{P}(\mathrm{y})
$$

where VO represents the heavy-duty vehicle ownership projection. In previous studies (Lv et al., 2019; Sun et al., 2016), heavy-duty vehicle populations were collected from public data sources, such as government websites and statistical yearbooks.

The next stage of the projection included emissions calculated using the IPCC method. It consisted of projections of VKT total per year, fuel consumption, and estimates of the $\mathrm{CO}_{2}$ emissions from heavy-duty vehicles. The VKT total was determined based on the heavy-duty vehicle population projection and the average VKT, using the following equation:

$$
\operatorname{VKT} \operatorname{total}(\mathrm{y})=\mathrm{VP}(\mathrm{y}) * \text { average VKT }
$$

where VP is the heavy-duty vehicle population projection and y is the year for which the estimate is being made.

In addition, future fuel consumption was estimated by the following equation:

$$
\mathrm{FC}(\mathrm{y})=\mathrm{VKT} \operatorname{total}(\mathrm{y}) / \mathrm{AFC}(\mathrm{v})
$$

where AFC represents average fuel consumption, based on Nasri and Utomo (2015), and v represents the type of heavy-duty vehicle.

Finally, the $\mathrm{CO}_{2}$ emissions of heavy-duty vehicles were projected, based on fuel consumption and specific GHG emission factors, using the following equation:

$$
\operatorname{VEL}(y)=F C(y) x \operatorname{EF}
$$


where EF represents specific GHG emission factors based on fuel type. An emission rate of $2.2 \mathrm{~kg} \mathrm{CO}_{2} / \mathrm{liter}$ was estimated for vehicles using diesel fuel.

\subsection{IPCC Guidelines}

The Intergovernmental Panel on Climate Change (IPCC) guidelines provide a methodology for estimating nation-level anthropogenic GHG emissions which factors in both GHG sources and sinks (Gollnow et al., 2014). The calculation of transportation GHG emissions in this study used the IPCC's bottom-up (or Tier 2) method. The bottom-up method calculates heavy-duty vehicle emissions based on Vehicle Kilometers Traveled (VKT) per year (IPCC, 2019). The following equation shows the general formula for calculating GHG emissions:

$$
\text { GHG Emission }\left(\mathrm{CO}_{2}\right)=\mathrm{VP} \times \mathrm{SEC} \times \mathrm{EF}
$$

where VP represents heavy-duty vehicle population, SEC represents specific energy consumption (calculated by dividing VKT (km/unit) by the fuel consumed $(\mathrm{km} / \mathrm{L})$ ), and EF represents specific GHG emission factors based on fuel type ( $\left.\mathrm{kg} \mathrm{CO}_{2} / \mathrm{L}\right)$. Since heavy-duty vehicles commonly consume diesel, according to Bappenas (2014), the specific GHG emission factor used was $2.2 \mathrm{~kg} \mathrm{CO} /$ liter.

\section{Results and Discussion}

\subsection{Heavy-duty Vehicle Population Projection}

Vehicle emissions in megacities are essentially related to the population of vehicles in the city (Sun et al., 2019). Table 1 shows the heavy-duty vehicle population from 2021 to 2030 . The total heavyduty vehicle population is projected to increase from around 60o,0oo in 2021 to 1,198,000 in 2030. In 2030, the number of trucks is projected to be higher than the number of buses; the number of trucks is projected to reach about 1,125,00o, representing 94\% of all heavy-duty vehicles. According to Amin et al. (2017), the vehicle population is affected by increases in population and per capita income (GDP). Vehicle population can also be predicted based on its relationship to GDP by using the elastic coefficient method (Liu et al., 2017). Heavy-duty vehicles are fundamentally different from passenger cars. The end-use of trucks varies widely-for instance, trucks are used for regional or long-haul delivery, municipality use, and for construction. Trucks vary in engine sizes, fuel tank sizes, cab sizes, chassis heights, and number of axles according to the specific end-use or purpose of each vehicle (ACEA, 2019).

Table 1. Heavy-duty vehicle population projection

\begin{tabular}{cccc}
\hline \multirow{2}{*}{ Year } & \multicolumn{3}{c}{ Vehicle } \\
\cline { 2 - 4 } & Buses & Trucks & Total \\
\hline $\mathbf{2 0 2 1}$ & 39,951 & 605,980 & 645,931 \\
\hline $\mathbf{2 0 2 2}$ & 42,515 & 646,769 & 689,284 \\
\hline $\mathbf{2 0 2 3}$ & 45,295 & 691,003 & 736,298 \\
\hline $\mathbf{2 0 2 4}$ & 48,309 & 738,984 & 787,293 \\
\hline $\mathbf{2 0 2 5}$ & 51,577 & 791,035 & 842,612 \\
\hline $\mathbf{2 0 2 6}$ & 55,121 & 847,513 & 902,634 \\
\hline $\mathbf{2 0 2 7}$ & 58,966 & 908,800 & 967,766 \\
\hline $\mathbf{2 0 2 8}$ & 63,137 & 975,317 & $1,038,454$ \\
\hline $\mathbf{2 0 2 9}$ & 67,663 & $1,047,517$ & $1,115,180$ \\
\hline $\mathbf{2 0 3 0}$ & 72,575 & $1,125,896$ & $1,198,471$ \\
\hline
\end{tabular}

On the other hand, it is estimated that $6 \%$ of all heavy-duty vehicles in 2030 will be buses, of which there are projected to be a total of 72,500 . Yu et al. (2016) state that the population of buses increases as passenger load increases. Traffic conditions also strongly influence the bus population and ultimately 
impact the amount of emissions which they produce. In Semarang, buses are usually used for daily longhaul and regional transportation.

\subsection{VKT Total}

The average vehicle kilometers traveled (VKT) was determined according to data obtained from service stations and heavy-duty vehicle dealers in Semarang City. Table 2 provides information on differences in the average VKT of trucks and buses. Trucks travel longer distances than buses: their VKT is $32,000 \mathrm{~km} /$ year and that of buses is $15,000 \mathrm{~km} /$ year. This difference is related to export-import activities and inter-regional goods deliveries (Anas and Sembiring, 2019). Furthermore, the VKTs of trucks and buses increase as GDP grows. It is necessary to have data indicating total VKT per year in order to project the future fuel consumption of vehicles. The VKT total of vehicles per year was calculated by multiplying the vehicle population by the average VKT per year.

Table 2 Average VKT

\begin{tabular}{cc}
\hline Buses (Km/year) & Trucks (Km/year) \\
\hline $15,699.56$ & $32,688.79$ \\
\hline
\end{tabular}

Table 3 presents information on the projection of the total VKT per year of trucks and buses. By 2030 truck VKT is projected to exceed 38 million $\mathrm{km} /$ year and bus VKT to exceed 15 million $\mathrm{km} /$ year. According to Huo et al. (2012), the purpose of a vehicle journey is one of the most critical factors influencing vehicle use. Trucks have more vpurposes than buses do. Therefore, VKT for trucks is higher than it is for buses. Studies carried out in Japan and the United States indicate that trucks travel longer distances than buses do because trucks are commonly used for long-distance transport (Wang et al., 2006).

Table 3 VKT total per year

\begin{tabular}{ccc}
\hline \multirow{2}{*}{ Year } & \multicolumn{2}{c}{ Vehicle (km/year) } \\
\cline { 2 - 3 } & Buses & Trucks \\
\hline 2021 & $627,206,264$ & $20,569,590,958$ \\
2022 & $667,470,971$ & $21,954,117,002$ \\
2023 & $711,114,522$ & $23,455,626,808$ \\
2024 & $758,430,539$ & $25,084,293,881$ \\
2025 & $809,737,474$ & $26,851,152,247$ \\
2026 & $865,382,913$ & $28,768,245,360$ \\
2027 & $925,742,775$ & $30,848,598,500$ \\
2028 & $991,228,472$ & $33,106,466,742$ \\
2029 & $1,062,284,391$ & $35,557,247,903$ \\
2030 & $1,139,395,723$ & $38,217,753,645$ \\
\hline
\end{tabular}

\subsection{Fuel Consumption}

Following the total VKT per year calculation, annual fuel consumption was estimated by dividing the total VKT per year by the average fuel consumption for each type of vehicle. According to Nasri and Utomo (2015), buses and trucks running on diesel have average fuel consumption rates of $2.8 \mathrm{~km} / \mathrm{l}$ and $3.8 \mathrm{~km} / \mathrm{l}$, respectively. Figure 1 presents the amount of fuel projected to be consumed by heavy-duty vehicles in each year between 2021 and 2030. Trucks are projected to consume more fuel than buses. Fuel consumption by trucks is projected to increase from 5.38 to 9.99 gigaliter/year by 2030 due to the high population and high total VKT per year. Buses, however, are projected to consume fuel at a rate of about 0.22 to 0.4 gigaliter/year. This increase in fuel consumption is influenced by several factors, including the increasing vehicle population, the large amount of discounted fuel provided by the government, and increases in per capita income (Tiarani et al., 2016). A previous study has found that trucks will be the 
largest fuel consumers among road vehicles in 2050 due to their high total VKT and high fuel consumption rates (Wang et al., 2006).

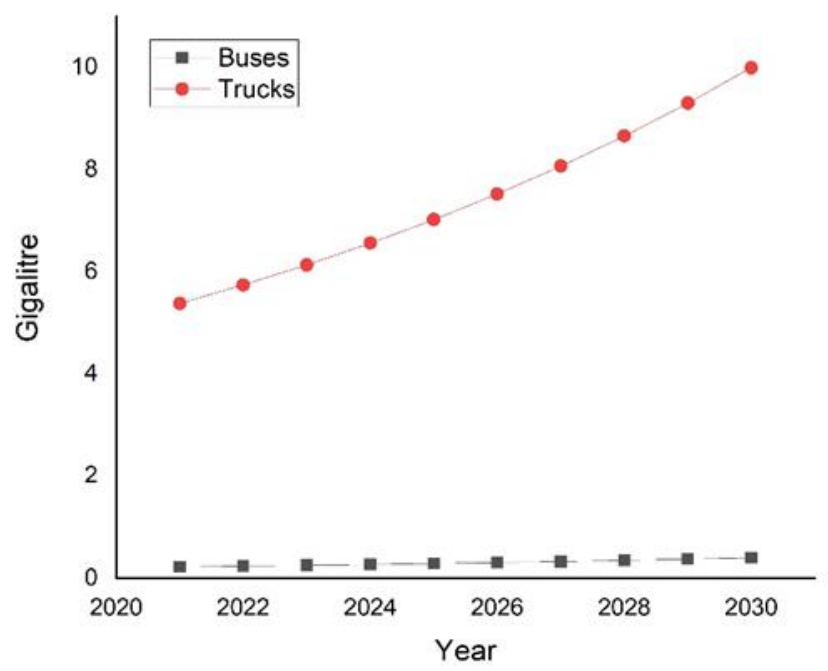

Figure 1 Fuel consumption from 2021-2030

\subsection{Heavy-duty Vehicle Emissions Load $\left(\mathrm{CO}_{2}\right)$}

From 2021 to 2030, the total emissions load $\left(\mathrm{CO}_{2}\right)$ from heavy-duty vehicles in Semarang City increased from 12,317 to 22,865 $\mathrm{Gg} \mathrm{CO}_{2}$ /year. Of this total, trucks were responsible 21,981.5 $\mathrm{Gg} \mathrm{CO}_{2}$ /year and buses for $884.2 \mathrm{Gg} \mathrm{CO}_{2}$ /year. Figure 2 indicates that trucks produce more emissions than buses. According to previous calculations, in comparison with buses there is a higher population of trucks, their total VKT is higher, and their average fuel consumption is higher. According to Wang et al. (2008), heavyduty vehicles are the primary sources of vehicular emissions in cities. This is consistent with the fact that heavy-duty vehicles mainly consume diesel with few controls on their emissions. Furthermore, the emission factors of heavy-duty vehicles are much higher than those of light-duty vehicles.

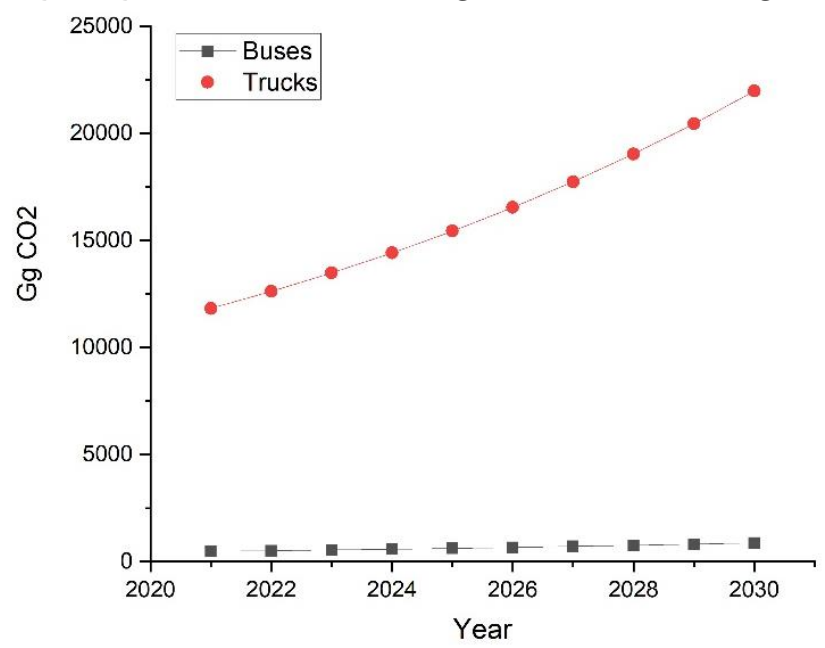

Figure 2 Heavy-duty vehicle emissions $\left(\mathrm{CO}_{2}\right)$ from 2021-2030

\section{Conclusion}

This study was conducted to construct a projection of heavy-duty vehicle emissions in Semarang City in order to support further studies and future policies dealing with road transportation emissions. This study used the BAU method for projection and the IPCC method to determine and project vehicle emissions. In Semarang City, the heavy-duty vehicle population is predicted to increase from around 600,000 to $1,198,000$ units by 2030 . The population of trucks is projected to remain higher than that of 
buses at a total number of 1,125,00o, representing $94 \%$ of the total number of heavy-duty vehicles in the city. On the other hand, the population of buses is projected to reach 72,500 by 2030 , representing $6 \%$ of the total number of heavy-duty vehicles in the city. Trucks have travel longer distances than buses: 38 million $\mathrm{km} /$ year and 15 million $\mathrm{km} /$ year, respectively. The total VKT of trucks is also higher than that of buses. Fuel consumption of heavy-duty vehicles is also projected to increase significantly by 2030 . Between 2021 and 2030, the total fuel consumption of Semarang's trucks is projected to increase from 5.38 to 9.99 gigaliter/year. Meanwhile, the total fuel consumption of buses is projected to increase from 0.22 to 0.4 gigaliter/year. Furthermore, heavy-duty vehicle emissions are projected to increase from $12,317 \mathrm{Gg}$ $\mathrm{CO}_{2}$ /year in 2021 to $22,865 \mathrm{Gg} \mathrm{CO} 2 /$ year in 2030, of which 21,981.5 $\mathrm{Gg} \mathrm{CO} 2$ /year will result from trucks and 884.2 $\mathrm{Gg} \mathrm{CO} 2$ /year from buses. Without changes to the type of fuel used, or a limit on the number of vehicles, emissions may increase even more rapidlyas a result of increases in vehicle population, VKT, and fuel consumption.

\section{Acknowledgment}

This research was funded by Direktorat Riset dan Pengembangan, Kementerian Riset dan Teknologi/Badan Riset dan Inovasi Nasional Tahun Anggaran 2020 No 225-103/UN7.6.1/PP/2020. The authors are grateful to Renanda Dennyarto and Fadhil Wicaksono for their help on facilitating focus group discussion for this research.

\section{References}

ACEA, E.A.M.A., 2019. CO2 emissions from heavy-duty vehicles.

Amin, M.C., Hamidi, W., Ekwarso, H., 2017. Faktor-faktor yang mempengaruhi pertumbuhan kendaraan bermotor roda dua di Kota Pekanbaru. Riau University.

Anas, R., Sembiring, I., 2019. A study of container truck movement in Tanjung Priok port, Jakarta, Indonesia, IOP Conference Series: Materials Science and Engineering. IOP Publishing, p. 012126.

Anenberg, S.C., Miller, J., Minjares, R., Du, L., Henze, D.K., Lacey, F., Malley, C.S., Emberson, L., Franco, V., Klimont, Z., 2017. Impacts and mitigation of excess diesel-related $\mathrm{NO} x$ emissions in 11 major vehicle markets. Nature 545, 467-471.

Bappenas, 2014. Pedoman Teknis Perhitungan Baseline Emisi Gas Rumah Kaca Sektor Berbasis Energi. Badan Perencanaan Pembangunan Nasional, Jakarta.

Central Bureau of Statistics of Semarang City, B., 2020. Kota Semarang dalam angka 2020, Semarang, Indonesia.

Gollnow, S., Lundie, S., Moore, A.D., McLaren, J., van Buuren, N., Stahle, P., Christie, K., Thylmann, D., Rehl, T., 2014. Carbon footprint of milk production from dairy cows in Australia. International Dairy Journal 37, 31-38.

He, J., Wu, L., Mao, H., Liu, H., Jing, B., Yu, Y., Ren, P., Feng, C., Liu, X., 2016. Development of a vehicle emission inventory with high temporal-spatial resolution based on NRT traffic data and its impact on air pollution in Beijing-Part 2: Impact of vehicle emission on urban air quality. Atmospheric Chemistry and Physics 16, 3171-3184.

Huo, H., Zhang, Q., He, K., Yao, Z., Wang, M., 2012. Vehicle-use intensity in China: Current status and future trend. Energy Policy 43, 6-16.

IPCC, 2019. Refinement of IPCC 2006 Guidelines for National Greenhouse Gas Inventories.

Japan Automobile Manufacturers Association, J., 20o8. Reducing CO2 Emissions in the Global Road Transport Sector. Tokyo: Japan Automobile Manufacturers Association, Inc.

Liu, Y.-H., Liao, W.-Y., Lin, X.-F., Li, L., Zeng, X.-1., 2017. Assessment of co-benefits of vehicle emission reduction measures for 2015-2020 in the Pearl River Delta region, China. Environmental pollution 223, 62-72.

Lv, W., Hu, Y., Li, E., Liu, H., Pan, H., Ji, S., Hayat, T., Alsaedi, A., Ahmad, B., 2019. Evaluation of vehicle emission in Yunnan province from 2003 to 2015. Journal of Cleaner Production 207, 814-825.

Ministry of Energy and Mineral Resources Republic of Indonesia, 2019. Handbook of Energy \& Economic Statistics of Indonesia 2019.

Nasri, M.F.A., Utomo, M.T.S., 2015. Prediksi Konsumsi Bahan Bakar Minyak Untuk Kendaraan Darat Jalan Raya Sampai Tahun 2040 Menggunakan Software Leap. Jurnal Teknik Mesin 3, 198-207. 
Pauzi, H.M., Abdullah, L., 2014. Performance comparison of two fuzzy based models in predicting carbon dioxide emissions, Proceedings of the First International Conference on Advanced Data and Information Engineering (DaEng-2013). Springer, pp. 203-211.

Song, C., He, J., Wu, L., Jin, T., Chen, X., Li, R., Ren, P., Zhang, L., Mao, H., 2017. Health burden attributable to ambient PM2. 5 in China. Environmental Pollution 223, 575-586.

Sun, S., Jiang, W., Gao, W., 2016. Vehicle emission trends and spatial distribution in Shandong province, China, from 2000 to 2014. Atmospheric Environment 147, 190-199.

Sun, S., Jin, J., Xia, M., Liu, Y., Gao, M., Zou, C., Wang, T., Lin, Y., Wu, L., Mao, H., 202o. Vehicle emissions in a middle-sized city of China: Current status and future trends. Environment International 137, 105514 .

Sun, S., Zhao, G., Wang, T., Jin, J., Wang, P., Lin, Y., Li, H., Ying, Q., Mao, H., 2019. Past and future trends of vehicle emissions in Tianjin, China, from 2000 to 2030. Atmospheric Environment 209, 182191.

Tiarani, V.L., Sutrisno, E., Huboyo, H.S., 2016. Kajian beban emisi pencemar udara (TSP, NOx, SO2, HC, $\mathrm{CO})$ dan gas rumah kaca $\left(\mathrm{CO}_{2}, \mathrm{CH}_{4}, \mathrm{~N}_{2} \mathrm{O}\right)$ sektor transportasi darat Kota Yogyakarta dengan metode tier 1 dan tier 2. Diponegoro University.

Wang, H., Chen, C., Huang, C., Fu, L., 2008. On-road vehicle emission inventory and its uncertainty analysis for Shanghai, China. Science of the Total Environment 398, 6o-67.

Wang, M., Huo, H., Johnson, L., He, D., 2006. Projection of Chinese motor vehicle growth, oil demand, and $\mathrm{CO}_{2}$ emissions through 2050, Argonne National Laboratory. Energy Systems Division 6.

Wu, T., Zhao, H., Ou, X., 2014. Vehicle ownership analysis based on GDP per capita in China: 1963-2050. Sustainability 6, 4877-4899.

Wu, X., Wu, Y., Zhang, S., Liu, H., Fu, L., Hao, J., 2016. Assessment of vehicle emission programs in China during 1998-2013: Achievement, challenges and implications. Environmental Pollution 214, 556567.

Wulandari, P.C., 2020. Estimasi Emisi Sektor Transportasi Dan Analisis Kemampuan Penyerapan Emisi Karbondioksida (Co2) Di Jalur Hijau Jalan Kenjeran Surabaya. Universitas Airlangga.

Yu, Q., Li, T., Li, H., 2016. Improving urban bus emission and fuel consumption modeling by incorporating passenger load factor for real world driving. Applied Energy 161, 101-111. 